\title{
ALTERATIONS IN SERUM AST, ALT AND ALKALINE PHOSPHATASE ACTIVITY DURING DIFFERENT DAYS OF FMD INFECTION IN LACTATING COWS
}

\author{
T. K. SAR*, R. BURAGOHAIN, S. AKHTAR AND T. K. MANDAL \\ Department of Veterinary Pharmacology and Toxicology \\ West Bengal University of Animal and Fishery Sciences \\ 37, K.B.Sarani, Kolkata - 700 037, India
}

\begin{abstract}
The present study aims monitoring of AST, ALT and alkaline phosphatase activity on different days in six healthy and six FMD affected lactating cows in field condition. The FMD affected six lactating cows were selected on the basis of clinical signs including high temperature, excessive salivation, formation of vesicles on the oral and nasal mucosa, the inter-digital spaces and coronary bands on the feet. Six apparently healthy lactating cows in the field condition were considered as control group. One $\mathrm{mL}$ of blood was collected aseptically from each cow from jugular vein at day $0,3,6,12$ and 21 . AST, ALT and alkaline phosphatase activity were estimated as per reported methods. AST activity was found to be increased significantly $(\mathbf{p}<0.05)$ on 0,3 and 6 day in FMD affected cows compared to healthy cows. Alkaline phosphatase activity was increased significantly $(p<0.05)$ on $0,3,6$ and 12 day in FMD affected cows compared to healthy cows indicating liver tissue damage. However, the alkaline phosphatase activity was observed to return to the normal level on day 21 in FMD affected cows without systemic application of any drug. Interestingly, ALT activity did not alter significantly in FMD affected cows compared to healthy cows. The observations may be correlated with liver impairment in FMD affected cows.
\end{abstract}

Key words: Alkaline phosphatase, ALT, AST, Cows, FMD

FMD is a highly contagious viral disease of cloven-hoofed animals, causing severe clinical signs including fever, lameness and vesicular lesions on tongue, muzzle, feet and teats (Arzt et al., 2011; Grubman and Baxt, 2004). FMD is caused by Picorna virus that also causes immune suppression in the affected animals (Cusick et al., 2004). FMD causes serious production losses, transmitted through multiple routes and hosts which make it one of the most important diseases affecting trade in

*Corresponding Author 
livestock. In cows, infection of udder and teats may progress to mastitis that causes milk loss (Wellenberga et al., 2002; Govindaraj et al., 2017). The economic loss per cow due to FMD was estimated to be Rupees 12,532 (Singh et al., 2013). A total of 1,082 FMD outbreaks were reported in the state of West Bengal, India during the 18 years from 1985 to 2002 (Bhattacharya et al., 2005). The liver impairment and alterations in AST, ALT and alkaline phosphatase in FMD in cattle has been studied earlier in cattle (Gattani et al., 2011). But, the alterations at different time interval have not yet been studied necessitating the present study.

The FMD affected six lactating cows were selected on the basis of clinical signs including high temperature, excessive salivation, formation of vesicles on the oral and nasal mucosa, the inter-digital spaces and coronary bands on the feet. One mililiter of blood was collected aseptically from each cow from jugular vein in test tubes at day $0,3,6,12$ and 21. Zero day collection was done in both healthy and FMD affected cows at field level and the enzyme activity values were compared between the two groups. Zero day collection from FMD affected cows was done when the affected cows started to show the clinical signs. ALT and AST activities were measured as per the method described by Yatazidis (1960). A standard curve for pyruvic acid was prepared previously with sodium pyruvate at different concentration and utilized for calculations. Estimation of alkaline phosphatase activity was done according to the method described by Bernt (1974). Mean values, standard error, and analysis of variance of the tabulated data were

Table 1. AST (IU/L), alkaline phosphatase (n mole $\rho N P ~ h r^{-1} \mathbf{m L}^{-1}$ ) and ALT (IU/L) activities on different days in healthy and FMD affected lactating cows

\begin{tabular}{ccccccc}
\hline Day & \multicolumn{2}{c}{ AST (IU/L) } & \multicolumn{2}{c}{$\begin{array}{c}\text { Alkaline phosphatase } \\
\left(\mathbf{n} \text { mole } \rho \mathbf{N P} \mathbf{~ h r}^{-1} \mathbf{m L}^{-1}\right)\end{array}$} & \multicolumn{2}{c}{ ALT (IU/L) } \\
\cline { 2 - 7 } & $\begin{array}{c}\text { Healthy } \\
\text { group }\end{array}$ & $\begin{array}{c}\text { FMD } \\
\text { group }\end{array}$ & $\begin{array}{c}\text { Healthy } \\
\text { group }\end{array}$ & $\begin{array}{c}\text { FMD } \\
\text { group }\end{array}$ & $\begin{array}{c}\text { Healthy } \\
\text { group }\end{array}$ & $\begin{array}{c}\text { FMD } \\
\text { group }\end{array}$ \\
\hline 0 & $27.534 \pm 1.406$ & $35.228 \pm 1.224^{* *}$ & $18.401 \pm 0.966$ & $24.106 \pm 1.134^{* * *}$ & $10.069 \pm 0.815$ & $12.489 \pm 1.019$ \\
3 & $27.385 \pm 1.345$ & $34.867 \pm 1.307^{* *}$ & $18.435 \pm 0.937$ & $23.856 \pm 1.124^{* *}$ & $10.328 \pm 0.735$ & $12.277 \pm 0.995$ \\
6 & $27.118 \pm 1.389$ & $31.801 \pm 1.185^{*}$ & $18.789 \pm 0.919$ & $23.460 \pm 0.897 * *$ & $10.856 \pm 0.718$ & $11.989 \pm 0.917$ \\
12 & $27.446 \pm 1.414$ & $29.035 \pm 1.307$ & $17.983 \pm 0.913$ & $22.144 \pm 0.878$ & $11.126 \pm 0.737$ & $11.586 \pm 0.787$ \\
21 & $27.631 \pm 1.393$ & $28.979 \pm 1.345$ & $18.567 \pm 0.967$ & $19.742 \pm 0.704$ & $10.896 \pm 0.789$ & $11.213 \pm 0.727$ \\
\hline
\end{tabular}

Significant differences were marked by $*(\mathrm{P}<0.05), * *(\mathrm{P}<0.01)$ 
calculated where applicable using the statistical software programme Mstat (Michigan State University, USA).

AST activity was significantly increased on day 0,3 and 6 in FMD affected lactating cows compared to healthy lactating cows (Table 1). Alkaline phosphatise activity was significantly increased on day $0,3,6$ and 12 in FMD affected lactating cows compared to healthy lactating cows (Table 1). ALT activity was non-significantly increased in FMD affected lactating cows on day 0,3 and 6 (Table 1). So, the significantly increased alkaline phosphates activity indicated liver damage in FMD affected cows which may be reversible as the enzyme activity returned to normal level on day 21. Significantly increased AST

\section{REFERENCES}

Arzt J, Juleff N, Zhang Z and Rodriguez LL, 2011. The pathogenesis of foot-andmouth disease I: viral pathways in cattle. Transbound Emerg Dis, 58: 291-304

Bernt E, 1974. Alkaline phosphatase assay. In: Bergmeter HU, Edn., Methods of Enzymatic Analysis. Academic Press, New York, pp 868

Bhattacharya S, Banerjee R, Ghosh R, Chattopadhayay AP and Chatterjee A, 2005. Studies of the outbreaks of foot and mouth disease in West Bengal, India, between 1985 and 2002. Rev Sci Tech Off Int Epiz, 24: 945-952 activity on day 0,3 and 6 indicated liver damage which was reflected in alkaline phosphatise activity in FMD affected lactating cows.

Gökçe et al. (2004) reported alkaline phosphatase value of $93.07 \pm 39.1 \mathrm{IU} / \mathrm{L}$ in FMD affected cows compared to $73.70 \pm$ 26.20 IU/L in healthy cows. But, Gattani et al. (2011) reported significantly increased serum AST activity and nonsignificantly increased ALT activity in FMD affected sheep in accordance with our present findings in FMD affected cows.

Therefore, our present study indicated that liver function impairment with liver tissue damage occurs in FMD affected lactating cows.

Cusick MF, Libbey JE and Fujinami RS, 2014. Picornavirus infection leading to immunosuppression. Future Virol, 9: 475-482

Gattani A, Gupta KK, Joshi G and Gupta SR. 2011. Metabolic profile of foot and mouth disease stressed sheep in semi arid region. $\mathrm{J}$ stress physiol biochem, 7 : 148-153

Govindaraj G, Ganeshkumar B, Nethrayini KR, Shalini $\mathrm{R}$ and Balamurugan $\mathrm{V}$ et al., 2017. Farm community impacts of foot and mouth disease outbreaks in cattle and buffaloes in Karnataka state, India. 
Transbound Emerg Dis, 64: 849-860

Grubman MJ and Baxt B. 2004. Foot-andmouth disease. Clin Microbiol Rev, 17: 465-493

Singh B, Prasad S, Sinha DK and Verma MR, 2013. Estimation of economic losses due to foot and mouth disease in India. Indian J Anim Sci, 83: 964-970

Wellenberga GJ, van der Poelb WHM, and Van Oirschot JT, 2002. Viral infections and bovine mastitis: a review. Vet Microbiol, 88: $27-45$

Yatazidis H, 1960. Measurement of transaminase in serum. Nature, 18: 7980

Gökçe G, Gökce HI, Günes V, Erdogan HM and Citil M, 2004. Alterations in some haematological and biochemical parameters in cattle suffering from foot and mouth Disease. Turk J Vet Anim Sci, 28: 723-727 